\title{
First record of the Asian clam Corbicula fluminea (Müller, 1774) (Bivalvia: Cyrenidae) at Poxim-Açu River, northeastern Brazil
}

\author{
Primeiro registro de ocorrência de Corbicula fluminea (Müller, 1774) \\ (Bivalvia: Cyrenidae) no rio Poxim-Açu, região nordeste do Brasil
}

\section{Leonardo Cruz da Rosa ${ }^{1 *}$ (D) and José Oliveira Dantas² (D)}

${ }^{1}$ Laboratório de Invertebrados Bentônicos, Departamento de Engenharia de Pesca e Aquicultura, Universidade Federal de Sergipe - UFS, Avenida Marechal Rondon s/n, Rosa Elze,

CEP 49100-000, São Cristóvão, SE, Brasil

${ }^{2}$ Instituto Federal de Educação, Ciência e Tecnologia de Sergipe - IFS, Rodovia BR 101, Km 96, Quissamã, CEP 49100-000, São Cristóvão, SE, Brasil

*e-mail: leonardo.rosa@rocketmail.com

Cite as: Rosa L. C. and Dantas J. O. First record of the Asian clam Corbicula fluminea (Müller, 1774) (Bivalvia: Cyrenidae) at Poxim-Açu River, northeastern Brazil. Acta Limnologica Brasiliensia, 2020, vol. 32, e22.

Abstract: Aim: The objective of this work is to provide a new occurrence record of the Asian clam Corbicula fluminea in the Poxim-Açu River, northeastern Brazil. Methods: Samplings were carried out on October 20th of 2016 at five sites along Poxim-Açu River. At each site five samples were taken with a PVC core of $0.25 \mathrm{~m}$ of diameter and all individuals found inside core were sorted by hand. Results: The species was recorded at all sites with densities ranging from $412 \pm 169$ to $1692 \pm 1474$ individuals $/ \mathrm{m}^{2}$. Conclusion: This record extends the distribution of C. fluminea at northeastern Brazil.

Keywords: non-native species; first record; Asian clam; Sergipe River basin.

Resumo: Objetivo: Esse trabalho tem como objetivo registrar pela primeira vez a presença do berbigão asiático Corbicula fluminea no Rio Poxim-Açu, região nordeste do Brasil. Métodos: As amostragens foram realizadas em 20 de outubro de 2016 em cinco pontos ao longo do Rio PoximAçu. Em cada ponto foram coletadas cinco amostras com o auxílio de um tudo de PVC (diâmetro de $0,25 \mathrm{~m}$ ). Todos os indivíduos presentes dentro do tubo foram coletados manualmente. Resultados: A espécie esteve presente em todos os pontos amostrais com densidades variando entre $412 \pm 169$ e $1692 \pm 1474$ indivíduos $/ \mathrm{m}^{2}$. Conclusão: Esse registro amplia a distribuição de $C$. fluminea na região nordeste do Brasil.

Palavras-chave: espécies exóticas; primeiro registro; berbigão asiático; bacia hidrográfica do Rio Sergipe. 
The introduction of non-native species is considered to be the second most important reason for biodiversity loss worldwide (Bellard et al., 2016). Among freshwater invertebrates, Corbicula fluminea (Müller, 1774) (Bivalvia: Cyrenidae) is one of the most important non-native invasive species in aquatic systems mainly due to its widespread distribution and ecological and economic impacts (Sousa et al., 2008; Crespo et al., 2015). This species is native from Southeast Asian but currently have spread to majority of freshwater systems worldwide (Mansur et al., 2004; Crespo et al., 2015). In South America, this species was first recognized around the 1970s in the Rio de la Plata estuary (Ituarte, 1981). VeitenheimerMendes (1981) recorded C. fluminea for the first time in Brazil, and since then several works showed its dispersion in the south (Mansur \& Garces, 1988), southeast (Avelar, 1999; Suriani et al., 2007; Vianna \& Avelar, 2010; Lima, 2017), central-west (Callil \& Mansur, 2002; Poleze \& Callil, 2015) and north (Beasley et al., 2003; Pimpão \& Martins, 2008) regions of the country. The species was also recorded in the northeastern region along São Francisco River (Santana et al., 2013).

In this work, the presence of C. fluminea is recorded for the second time in the Northeastern
Brazil and by first time in the Poxim-Açu River. The Poxim-Açu River is part of the Poxim River sub-basin, which belongs to the Sergipe River basin (Figure 1). The sub-basin has an area of $128 \mathrm{~km}^{2}$, $10 \%$ winding index, 4 th order river hierarchy and compactness coefficient of 1.76 , with elongated and practically straight form and low tendency to flood peaks (Rocha et al., 2014). The Poxim River basin contributes to about $30 \%$ of the water supply of Aracaju city, state capital. Despite its social and economic importance, this sub-basin is in a high level of environmental degradation, especially with regard to the suppression of its riparian vegetation (Ferreira et al., 2011).

Samplings were carried out on October 20th of 2016 at five sites along Poxim-Açu River (Figure 1). Five samples were taken at each site using a PVC core of $0.25 \mathrm{~m}$ of diameter which was pushed $10 \mathrm{~cm}$ into the sediment. All individuals found inside were taken by hand and stored in plastic bags properly identified. At lab, individuals were identified and counted. Individuals of $C$. fluminea (Figure 2) were caught at all sampling sites with densities ranging from $412 \pm 169$ (Site 5) to $1692 \pm 1474$ individuals $/ \mathrm{m}^{2}$ (Site 3) (Figure 3).

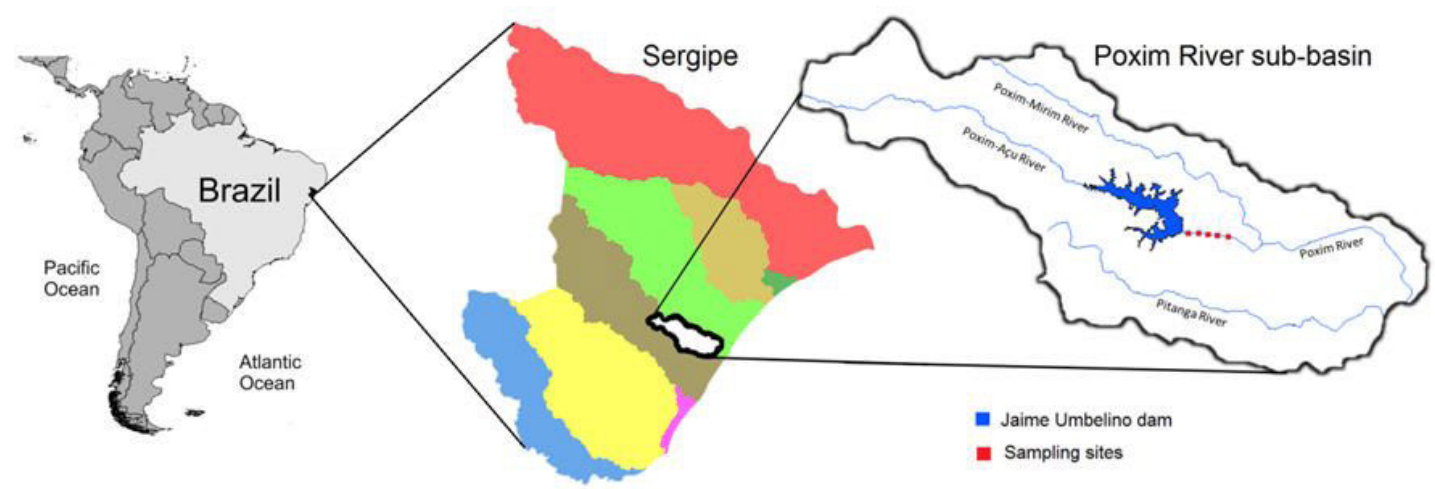

Figure 1. Map of Poxim River sub-basin indicating the sampling sites.
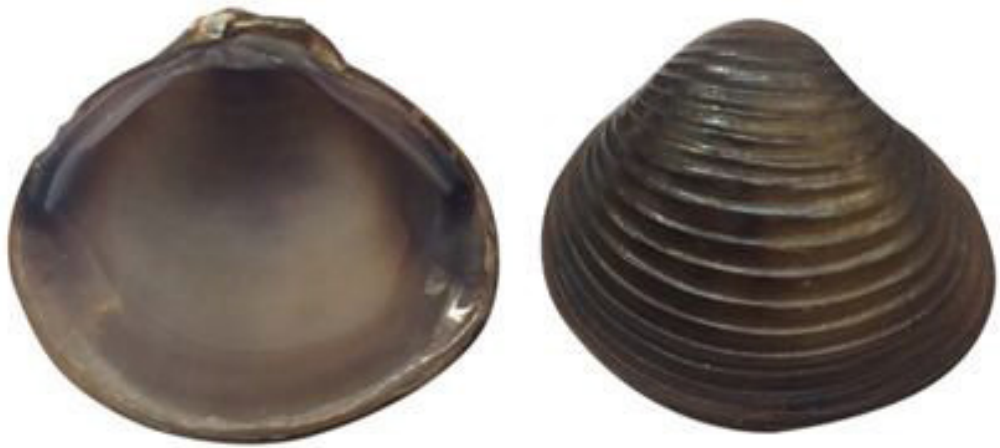

Figure 2. Internal and external views of valves of the Corbicula fluminea caught at Poxim-Açu River. $S c a l e=1 \mathrm{~cm}$. 


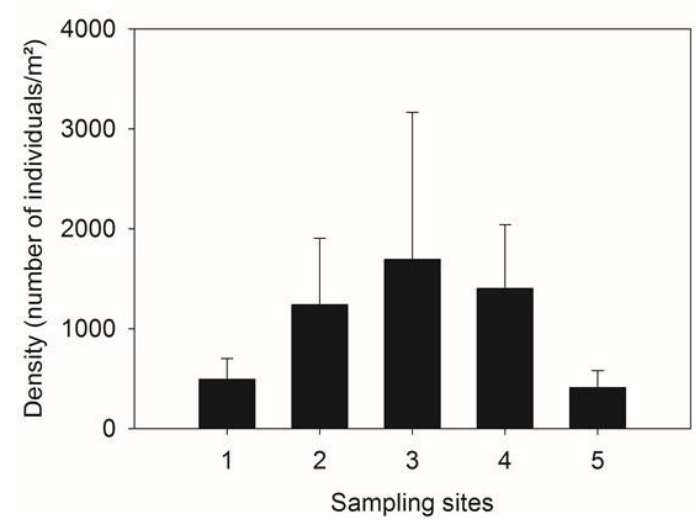

Figure 3. Mean densities (+ 1 standard deviation) of Corbicula fluminea in each sampling site at Poxim-Açu River.

The transport vector of $C$. fluminea into the Poxim-Açu River is unknown but the high densities recorded suggest that the species is already established. Similar values (from 379 to 2609 individuals $/ \mathrm{m}^{2}$ ) were recorded by Cataldo \& Boltovskoy (1998) in the Paraná River delta, Argentina.

In general, the introduction and subsequent dispersion of $C$. fluminea in aquatic ecosystems is a result of various human activities such as ballast water transport or the juvenile byssal attachment to boat hulls (Sousa et al., 2008; Crespo et al., 2015). Additionally, this species has extensive capacities for natural dispersion since the pediveliger and juveniles are also passively transported adhered with a byssal attachment to mobile animals such as aquatic birds (Sousa et al., 2008; Crespo et al., 2015). This species was previously recorded at Sáo Francisco River, approx. 200km away from Poxim-Açu River. However, since there are no boat navigations at Poxim-Açu River, is probable that dispersion to this new place occurred by natural ways though passive transport of individual adhered to aquatic birds.

The establishment of non-native species is often favored by human disturbances such as the construction of reservoirs for either hydropower generation or water supply for human consumption, which changes environmental conditions and makes vulnerable aquatic ecosystems more susceptible to invasion (Poleze \& Callil, 2015). Coincidentally, this record of $C$. fluminea occurs just after the building of a dam situated a few kilometers upstream the sampling sites. The dam was built by Sanitation Company of State to provide water supply for human consumption and started to operate in 2013.
Besides negative ecological impacts, the presence of the $C$. fluminea has also resulted in negative economic impacts as the species cause obstruction of pipelines, channels, cooling systems of industries and hydroelectric power plants. Shutdown of hydroelectric power plants and water supply systems by $C$. fluminea has already been registered in Southeast Brazil (Santos et al., 2012).

In this way, the present new record of the Corbicula fluminea in the Poxim-Açu River is a contribution to a better knowledge about the species distribution, especially at Northeastern Brazil. Also, this finding reinforces the need for a monitoring program to evaluate the possible ecological and economic impacts on this ecosystem.

\section{Acknowledgement}

We thank to Dra. Maria Cristina Mansur for helping in the species identification.

\section{References}

AVELAR, W.E.P. Moluscos bivalves. Biodiversidade de Estado de São Paulo, Brasil: síntese do conhecimento ao final do século XX. In: D. ISMAEL, W.C. VALENTI, T. MATSUMURA-TUNDISI and O. ROCHA, eds. Invertebrados de água doce. São Paulo: Fapesp, 1999, pp. 65-68. vol. 4.

BEASLEY, C.R., TAGLIARO, C.H. and FIGUEIREDO, W.B. The occurrence of the Asian clam Corbicula fluminea in the lower Amazon basin. Acta Amazonica, 2003, 33(2), 317-324. http://dx.doi. org/10.1590/1809-4392200332324.

BELLARD, C., CASSEY, P. and BLACKBURN, T.M. Alien species as a driver of recent extinctions. Biology Letters, 2016, 12(2), 20150623. http://dx.doi. org/10.1098/rsbl.2015.0623. PMid:26888913.

CALLIL, C.T. and MANSUR, M.D.C. Corbiculidae in the Pantanal: history of invasion southeast and central South America and biometrical data. Amazoniana, 2002, 17(1-2), 153-167.

CATALDO, D. and BOLTOVSKOY, D. Population dynamics of Corbicula fluminea (Bivalvia) in the Paraná River delta, Argentina. Hydrobiologia, 1998, 380(1-3), 153-163. http://dx.doi. org/10.1023/A:1003428728693.

CRESPO, D., DOLBETH, M., LESTON, S., SOUSA, R. and PARDAL, M.A. Distribution of Corbicula fluminea (Müller, 1774) in the invaded range: a geographic approach with notes on species traits variability. Biological Invasions, 2015, 17(7), 2087-2101. http://dx.doi.org/10.1007/s10530015-0862-y.

FERREIRA, R.A., AGUIAR-NETTO, A.O., SANTOS, T.I.S., SANTOS, B.L. and MATOS, E.L. Nascentes da sub-bacia hidrográfica do Rio Poxim, estado de 
Sergipe: da degradação à restauração. Revista Árvore, 2011, 35(2), 265-277. http://dx.doi.org/10.1590/ S0100-67622011000200011.

ITUARTE, C.F. Primera noticia acerca de la presencia de pelecípodos asiáticos en el area rioplatense. Neotrópica, 1981, 27, 79-82.

LIMA, J.C.S. Novos registros de Corbicula fluminea (Müller, 1774) (Bivalvia, Corbiculidae) no sudeste do Brasil. Revistas de Ciências Ambientais, 2017, 11(2), 7-11. http://dx.doi.org/10.18316/rca.v11i2.2584.

MANSUR, M.C.D., CALLIL, C.T., CARDOSO, F.F. and IBARRA, J.A.A. Uma retrospectiva e mapeamento da invasão de espécies de Corbicula (Mollusca, Bivalvia, Veneroida, Corbiculidae) oriundas do sudeste asiático, na América do Sul. In: J.S.V. SILVA and R.C.C.L. SOUZA, eds. Água de lastro e bioinvasão. Rio de Janeiro: Interciência, 2004, pp. 39-58.

MANSUR, M.C.D. and GARCES, L.M.M.P. Ocorrência e densidade de Corbicula fluminea (Muller, 1774) e Neocorbicula limosa (Maton, 1811) na Estação Ecológica do Taim e áreas adjacentes, Rio Grande do Sul, Brasil (Mollusca, Bivalvia, Corbiculidae). Iheringia. Série Zoologia, 1988, 68, 99-115.

PIMPÁO, D.M. and MARTINS, D.S. Ocorrência do molusco asiático Corbicula fluminea (Müller, 1774) (Bivalvia, Corbiculidae) no baixo rio Negro, Amazônia central. Acta Amazonica, 2008, 38(3), 589-592. http://dx.doi.org/10.1590/S004459672008000300026 .

POLEZE, M. and CALLIL, C.T. Bivalvia, Cyrenidae, Corbicula fluminea (Müller, 1774): New record, density, and population structure in the Teles Pires River, northern Mato Grosso, Brazil. Check List, 2015, 11(4), 1720. http://dx.doi.org/10.15560/11.4.1720.

ROCHA, R.M., LUCAS, A.A.T., ALMEIDA, C.A.P., MENEZES-NETO, E.L. and AGUIAR-NETTO, A.O. Caracterização morfométrica da sub-bacia do rio PoximAçu, Sergipe, Brasil. Revista Ambiente \& Água, 2014, 9(2), 276-287. http://dx.doi.org/10.4136/1980-993X.

SANTANA, D., SILVA, M., BOCCHIGLIERI, A., PANTALEÃO, S., FARIA, R., SOUZA, B., ROCHA, S. and LIMA, L. Mollusca, Bivalvia,
Corbiculidae, Corbicula fluminea (Müller, 1774): First record for the Caatinga biome, northeastern Brazil. Check List, 2013, 9(5), 1072-1074. http:// dx.doi.org/10.15560/9.5.1072.

SANTOS, S.B., THIENGO, S.C., FERNANDEZ, M.A., MIYAHIRA, I.C., GONÇALVES, I.C.B., XIMENES, R.F., MANSUR, M.C.D. and PEREIRA, D. Espécies de moluscos límnicos invasores no Brasil. In: M.C.D. MANSUR, C.P. SANTOS, D. PEREIRA, I.C.P. PAZ, M.L.L. ZURITA, M.T.R. RODRIGUES, M.V. NERHKE and P.A. BERGONCI, eds. Moluscos limnicos invasores no Brasil: biologia, prevenção e controle. Porto Alegre: Redes Editora, 2012, pp. 25-49.

SOUSA, R., ANTUNES, C. and GUILHERMINO, L. Ecology of the invasive Asian clam Corbicula fluminea (Müller, 1774) in aquatic ecosystems: an overview. Annales de Limnologie, 2008, 44(2), 85-94. http:// dx.doi.org/10.1051/limn:2008017.

SURIANI, A.L., FRANÇA, R.S. and ROCHA, O. A malacofauna bentônica das represas do médio Tietê e uma avaliação ecológica das espécies exóticas invasoras, Melanoides tuberculata (Müller) e Corbicula fluminea (Müller). Revista Brasileira de Zoologia, 2007, 24(1), 21-32. http://dx.doi.org/10.1590/ S0101-81752007000100003.

VEITENHEIMER-MENDES, I.L. Corbicula manilensis (Philippi, 1844) molusco asiático, na bacia do Jacuí e do Guaíba, Rio Grande do Sul, Brasil (Bivalvia, Corbiculidae). Iheringia. Série Zoologia, 1981, 60, 63-74.

VIANNA, M. and AVELAR, W. Ocorrência da espécie invasora Corbicula fluminea (Bivalvia, Corbiculidae) no rio Sapucaí (São Paulo, Brasil). Biotemas, 2010, 23(3), 59-66. http://dx.doi.org/10.5007/21757925.2010v23n3p59.

Received: 24 September 2019 Accepted: 20 July 2020

Associate Editor: André Andrian Padial. 